\title{
THE VALIDITY OF GENES RELATED TO NEUROTRANSMITTERS AS INSTRUMENTAL VARIABLES
}

\author{
JOHN CAWLEY ${ }^{\mathrm{a}, *}$, EUNA HAN ${ }^{\mathrm{b}}$ and EDWARD C. NORTON \\ ${ }^{\text {a }}$ Cornell University, $N Y, U S A$ \\ ${ }^{\mathrm{b}}$ Gachon University of Medicine and Science, Inchon, South Korea \\ ${ }^{\mathrm{c}}$ University of Michigan, MI, USA
}

Health economics has a tradition of evaluating the models of instrumental variables (IV) used in our field. For example, French and Popovici (2011) assess the instruments used in 60 recent studies measuring the effect of substance use (alcohol, illicit drugs, and tobacco) on various outcomes. Rashad and Kaestner (2004) evaluate the instruments used by Sen (2002) and Rees and colleagues (2001) to identify the effect of alcohol on risky sex among adolescents. Terza et al. (2008) review the health economics literature that applies linear IV methods in inherently nonlinear regression settings.

In this editorial we discuss the IVs used in Fletcher and Lehrer (2009a), hereafter FL, to estimate the effect of health conditions on educational attainment. We focus on FL because it is novel, well-written, and careful in many ways; it won the 2009 Victor R. Fuchs award for 'the best research paper with the potential to spawn new research in an underdeveloped area of health economics or health policy'. The use of genes as IVs (and in other empirical capacities) is likely to become more widespread as large social science datasets continue to add data from genetic assays. Therefore, consideration of this method is timely and likely to be useful in the future. Our comments should not be interpreted as exclusively about FL, but also apply to other papers in this emerging area of empirical health economics (e.g. Ding et al., 2009; Fletcher and Lehrer, 2009b), including our own (Norton and Han, 2008).

FL estimate IV models using data from the third wave of the National Longitudinal Survey of Adolescent Health (Add Health) to test whether overweight (based on self-reported weight and height), depression (based on the 20-item Center for Epidemiologic Studies-Depression Scale), and attention deficit and hyperactivity disorder or ADHD (based on 18 retrospective questions) affect years of schooling completed when respondents were on average 22 years old. FL argue persuasively that these measures of physical and mental health are endogenous to educational attainment. For example, poor grades in school may contribute to depression (reverse causality) and unobserved factors, such as rate of time preference, may contribute to both poor health and worse educational outcomes. As a result, simple regression would result in biased estimates of the effect of health on educational attainment.

FL address the endogeneity of health by using genes as IVs. The specific IVs they use, listed in column 1 of Table I, are genes related to the neurotransmitters dopamine and serotonin. Fletcher and Lehrer (2009b) note that geneticists have linked these specific genes to overweight, depression, and ADHD, and that these correlations make sense in light of the fact that neurotransmitters affect mood, attention, and are associated with feelings of pleasure and reward, and thus serve as positive reinforcement for certain decisions. For example, people who are genetically predisposed to low levels

*Correspondence to: Cornell University, NY, USA. E-mail: jhc38@cornell.edu 
Table I. Genes related to neurotransmitters that are used as instruments in Fletcher and Lehrer (2009a)

\begin{tabular}{|c|c|c|}
\hline Name of gene & Perceived function & Linked to which conditions that threaten validity? \\
\hline $\begin{array}{l}\text { SLC6A3 locus } \\
\text { (DAT1) }\end{array}$ & Regulates reuptake of dopamine & $\begin{array}{l}\text { Alcoholism (Muramatsu and Higuchi, 1995) } \\
\text { Affinity for delinquent peers (Beaver et al., 2008) } \\
\text { Generalized anxiety, social phobia, obsessive-compulsive } \\
\text { disorder, and Tourette's (Rowe et al., 1998) } \\
\text { Externalizing behavior problems such as aggressive and } \\
\text { delinquent behavior (Young et al., 2002) } \\
\text { Drug use, delinquency, and other risky behaviors (Guo } \\
\text { et al., 2010) } \\
\text { Bipolar disorder (Serretti and Mandelli, 2008) }\end{array}$ \\
\hline $\begin{array}{l}\text { Dopamine receptor } \\
\text { D2 locus (DRD2) }\end{array}$ & $\begin{array}{l}\text { Regulates density of D2 dopamine recep- } \\
\text { tors on neurons in the brain }\end{array}$ & $\begin{array}{l}\text { Schizophrenia (Arinami et al., 1997) } \\
\text { Alcoholism (Samochowiec et al., 2006) } \\
\text { Bipolar disorder (Zhan et al., 2010) } \\
\text { Impulsive self-damaging behaviors (Nemoda et al., 2010) }\end{array}$ \\
\hline $\begin{array}{l}\text { Dopamine D4 } \\
\text { receptor (DRD4) }\end{array}$ & $\begin{array}{l}\text { Codes D4 dopamine receptors, which may } \\
\text { vary in the affinity with which they bind } \\
\text { with dopamine }\end{array}$ & $\begin{array}{l}\text { Schizophrenia and heroin addiction (Lai et al., 2010) } \\
\text { Addictions of many kinds (McGeary, 2009) } \\
\text { Personality traits such as novelty seeking and impulsivity } \\
\text { (Munafò et al., 2008) } \\
\text { Borderline personality disorder (Nemoda et al., 2010) } \\
\text { Bipolar disorder (Serretti and Mandelli, 2008) }\end{array}$ \\
\hline $\begin{array}{l}\text { Serotonin transporter } \\
(5 \mathrm{HTT})\end{array}$ & Regulates reuptake of serotonin & $\begin{array}{l}\text { Aggression and violence (Craig, 2007) } \\
\text { Obsessive compulsive disorder (Wendland et al., 2008) } \\
\text { Anxiety (Lesch et al., 1996) } \\
\text { Suicide and suicidal behavior (Anguelova et al., 2003) } \\
\text { Bipolar disorder (Cho et al., 2005) }\end{array}$ \\
\hline $\begin{array}{l}\text { Monoamine oxidase } \\
\text { A (MAOA) }\end{array}$ & $\begin{array}{l}\text { Regulates the degradation of dopamine, } \\
\text { serotonine, and nenorepinephrine }\end{array}$ & $\begin{array}{l}\text { Aggression and violence (Craig, 2007) } \\
\text { Autism severity (Cohen et al., 2011) } \\
\text { Moderates children's sensitivity to environmental insults } \\
\text { (Caspi et al., 2002) }\end{array}$ \\
\hline
\end{tabular}

Note: The articles cited in the final column also represent the sources for the perceived functions of the genes.

of dopamine and serotonin may be at greater risk of 'self-medicating' by overeating. The specific genes used as instruments by FL affect levels of neurotransmitters in the brain in a variety of ways; e.g. by regulating the amounts released, the number of receptors that the neurotransmitters can bind to, and the rate of reuptake (see column 2 of Table I for more information on the perceived function of each gene).

The problem with using genes that relate to neurotransmitters as instruments in this context is that they may be associated with too many things to satisfy the exclusion restriction. This is particularly relevant when studying outcomes such as educational attainment, because it requires the unattractive identifying assumption that genes that affect brain chemistry do not affect educational attainment, except through obesity, depression, and ADHD.

A search of the genetics literature (via the biomedical and life science journal search indexes PubMed Central and Medline as well as the website http://www.wikigenes.org) yields many studies that link these specific genes to conditions that are likely to be unobserved determinants of educational attainment. The final column of Table I lists, for each gene, selected conditions to which the gene has been linked (with citations to the relevant genetics literature) that threaten its validity as an instrument in this context. The conditions associated with those genes include: generalized anxiety, social phobia, obsessive-compulsive disorder, aggression, delinquency, self-damaging behaviors, schizophrenia, bipolar disorder, novelty seeking and impulsivity, borderline personality disorder, suicidal behavior, autism severity, affinity for antisocial peers, and a wide range of addictive behaviors including alcoholism and drug addiction. These conditions and behaviors are not controlled for in the IV models 
of FL; moreover, it would likely be impossible to control for them because many are not observed in the Add Health data (or other large secondary datasets that economists commonly use). As a result, genes for neurotransmitters are likely correlated with residual educational attainment in the second stage of IV models, resulting in biased IV estimates. FL conduct overidentification tests, but this relies upon assuming that one or more genes are valid instruments. The findings cited in Table I imply that genes associated with neurotransmitters may be associated with too many relevant conditions to be valid instruments in this context.

For this reason, the use of genes related to neurotransmitters as instruments has been criticized by researchers outside of economics. Conley (2009, pp. 242-243) writes: 'Does DRD4 only affect school performance through the pathway of diagnosed ADHD? Of course not. ADHD is a complicated syndrome that involves lots of measurement error and thus most likely reflects a whole host of other unmeasured traits. And even if ADHD were measured perfectly by the researchers, there may be other effects of the genes in question on educational outcomes through any number of mechanisms, thereby violating the exclusion restriction necessary for unbiased IV estimation.'

\section{RECOMMENDED BEST PRACTICES}

The standards for empirical work in economics are continually rising; for example, recent IV papers contain much more information about power and tests of overidentification than those written during the 1980s. Part of the reason for evaluating recent IV papers is to recommend best practices in order for the field to continue to advance and improve (see, e.g. French and Popvici, 2011; Terza et al., 2008).

The general advice of Angrist and Krueger (2001) and Angrist and Pischke (2009) can be adapted to this specific case. We highlight a few of the many considerations that should be addressed in such analyses. Studies should include a clear description of how the set of instruments was chosen (i.e. which genes and which alleles of those genes). For example, FL report selecting their instruments through stepwise regression, which is an ad hoc method that results in overestimation of the instruments' power in the first stage. There should also be a clear description of the mechanisms by which each genetic instrument is expected to affect the endogenous regressor, with citations to the relevant genetics literature. Authors should provide the results of the first-stage regressions, so readers can determine whether the coefficients on the instruments have the expected sign given the findings in the genetics literature and thus whether the hypothesized mechanisms are plausible. In addition, papers should include a summary of the process and results of the literature search that was done to investigate whether the specific genes used as instruments are linked to any conditions that are likely to be correlated with the error term in the second stage, and would thus raise concerns about the validity of the instruments and bias in the IV estimates. Adhering to these practices when using genes as instruments will better communicate to readers the strengths and weaknesses of the IV approach. These recommendations are not directed solely at FL but are intended for the entire emerging literature that uses genes as instruments.

There may in some instances be a biological mechanism that serves as the identifying assumption, explaining both a link between the genetic instruments and the endogenous regressor and justifying the exclusion restriction. An ideal instrument would be a gene that acts as a switch, turning on or off one characteristic (that affects the endogenous regressor) while affecting no other characteristics (that would affect the second-stage error term). However, Conley (2009) is skeptical; he notes that humans have only 21000 genes to code for the vast number of individual characteristics and thus genes tend not to act as individual, isolated switches but instead act in concert with many other genes to affect a large number of characteristics. Although it is too early to say, it is possible that what we conclude about genes for neurotransmitters - that they may affect too many things to be valid instruments in most contexts may be true of many other genes as well. 
However, we remain optimistic that genes can be useful in economics research. For example, it may be possible to use genes related to neurotransmitters to test for peer effects in risky behaviors (Cawley et al., 2010). Specifically, if one had data on randomly assigned roommates (as in, e.g. Sacerdote, 2001; Duncan et al., 2005) including their genetic assays, one could regress the risky behaviors of one roommate directly on the other roommate's genes related to neurotransmitters. The fact that genes related to neurotransmitters affect many things is not a problem in this context, because the genes of one person can affect a different person's behavior only through peer effects. In this context, randomized assignment of peers is necessary because assortative matching of peers based on those genes may result in a spurious correlation between the behavior of the respondent and the genes of his chosen peers.

As science progresses, behavioral geneticists will learn more about which genes affect which aspects of health and through what mechanisms; this will provide economists with more information about which genes might be powerful and valid instruments in a given context. In the meantime, economists should proceed with caution when using genes, particularly those related to neurotransmitters, as instruments.

\section{ACKNOWLEDGEMENTS}

We are grateful to John Mullahy for his helpful comments and suggestions.

\section{REFERENCES}

Angrist JD, Krueger AB. 2001. Instrumental variables and the search for identification: from supply and demand to natural experiments. Journal of Economic Perspectives 15: 69-85.

Angrist JD, Pischke J. 2009. Mostly Harmless Econometrics: An Empiricist's Companion. Princeton University Press: Princeton, NJ.

Anguelova M, Benkelfat C, Turecki G. 2003. A systematic review of association studies investigating genes coding for serotonin receptors and the serotonin transporter: II. Suicidal behavior. Molecular Psychiatry 8(7): 646-653.

Arinami T, Gao M, Hamaguchi H, Toru M. 1997. A functional polymorphism in the promoter region of the dopamine D2 receptor gene is associated with schizophrenia. Human Molecular Genetics 6: 577-582.

Beaver KM, Wright JP, DeLisi M. 2008. Delinquent peer group formation: evidence of a gene $\mathrm{x}$ environment correlation. Journal of Genetic Psychology 169(3): 227-244.

Caspi A, McClay J, Moffitt TE, Mill J, Martin J, Craig IW et al. 2002. Role of genotype in the cycle of violence in maltreated children. Science 297: 851-854.

Cawley J, Norton EC, Han E. 2010. Identifying the Peer Effect of Obesity Using Genetic Lotteries, Presentation, American Society of Health Economists Biennial Conference, Ithaca, NY.

Cho HJ, Meira-Lima I, Cordeiro Q et al. 2005. Population-based and family-based studies on the serotonin transporter gene polymorphisms and bipolar disorder: a systematic review and meta-analysis. Molecular Psychiatry 10(8): 771-781.

Cohen IL, Liu X, Lewis ME, Chudley A, Forster-Gibson C, Gonzalez M, Jenkins E, Brown WT, Holden JJ. 2011. Autism severity is associated with child and maternal MAOA genotypes. Clinical Genetics 79(4): 355-362.

Conley D. 2009. The promise and challenges of incorporating genetic data into longitudinal social science surveys and research. Biodemography and Social Biology 55(2): 238-251.

Craig IW. 2007. The importance of stress and genetic variation in human aggression. Bioessays 29(3): $227-236$.

Ding W, Lehrer SF, Rosenquist JN, Audrain-McGovern J. 2009. The impact of poor health on academic performance: new evidence using genetic markers. Journal of Health Economics 28(3): 578-597.

Duncan GJ, Boisjoly J, Kremer M, Levy DM, Eccles J. 2005. Peer effects in drug use and sex among college students. Journal of Abnormal Child Psychology 33(3): 375-385.

Fletcher JM, Lehrer SF. 2009a. The effects of adolescent health on educational outcomes: causal evidence using genetic lotteries between siblings. Forum for Health Economics \& Policy 12(2). Article 8. 
Fletcher JM, Lehrer SF. 2009b. Using genetic lotteries within families to examine the causal impact of poor health on academic achievement. NBER Working Paper $\# 15148$.

French MT, Popovici I. 2011. That instrument is lousy! In search of agreement when using instrumental variables estimation in substance use research. Health Economics 20(2): 127-146.

Guo G, Cai T, Guo R, Wang H, Harris KM. 2010. The dopamine transporter gene, a spectrum of most common risky behaviors, and the legal status of the behaviors. PLoS One 5(2): e9352.

Lai JH, Zhu YS, Huo ZH, Sun RF, Yu B, Wang YP, Chai ZQ, Li SB. 2010. Association study of polymorphisms in the promoter region of DRD4 with schizophrenia, depression, and heroin addiction. Brain Research 1359: $227-232$.

Lesch KP, Bengel D, Heils A, Sabol SZ, Greenberg BD, Petri S, Benjamin J, Müller CR, Hamer DH, Murphy DL. 1996. Association of anxiety-related traits with a polymorphism in the serotonin transporter gene regulatory region. Science 274(5292): 1527.

McGeary J. 2009. The DRD4 exon 3 VNTR polymorphism and addiction-related phenotypes: a review. Pharmacology Biochemistry and Behavior 93(3): 222-229.

Munafò MR, Yalcin B, Willis-Owen SA, Flint J. 2008. Association of the dopamine D4 receptor (DRD4) gene and approach-related personality traits: meta-analysis and new data. Biological Psychiatry 63(2): 197-206.

Muramatsu T, Higuchi S. 1995. Dopamine transporter gene polymorphism and alcoholism. Biochemical and Biophysical Research Communications 211: 28-32.

Nemoda Z, Lyons-Ruth K, Szekely A, Bertha E, Faludi G, Sasvari-Szekely M. 2010. Association between dopaminergic polymorphisms and borderline personality traits among at-risk young adults and psychiatric inpatients. Behavioraland Brain Functions 6: 4.

Norton EC, Han E. 2008. Genetics, obesity, and labor market outcomes. Health Economics 17(9): 1089-1104.

Rashad I, Kaestner R. 2004. Teenage sex, drugs and alcohol use: problems identifying the cause of risky behaviors. Journal of Health Economics 23: 493-503.

Rees DI, Argys LM, Averett SL. 2001. New evidence on the relationship between substance use and adolescent sexual behavior. Journal of Health Economics 20: 835-845.

Rowe DC, Stever C, Gard JMC, Cleveland HH, Sanders ML, Abramowitz A et al. 1998. The relation of the dopamine transporter gene (DAT1) to symptoms of internalizing disorders in children. Behavioral Genetics $\mathbf{2 8}$ : $215-225$.

Sacerdote B. 2001. Peer effects with random assignment: results for Dartmouth roommates. Quarterly Journal of Economics 116(2): 681-704.

Samochowiec J, Kucharska-Mazur J, Grzywacz A, Jabłoński M, Rommelspacher H, Samochowiec A, Sznabowicz M, Horodnicki J, Sagan L, Pełka-Wysiecka J. 2006. Family-based and case-control study of DRD2, DAT, 5HTT, COMT genes polymorphisms in alcohol dependence. Neuroscience Letters 410(1): 1-5.

Sen B. 2002. Does alcohol-use increase the risk of sexual intercourse among adolescents? Evidence from the NLSY97. Journal of Health Economics 21(6): 1085-1093.

Serretti A, Mandelli L. 2008. The genetics of bipolar disorder: genome 'hot regions,' genes, new potential candidates and future directions. Molecular Psychiatry 13(8): 742-771.

Terza JV, Bradford WD, Dismuke CE. 2008. The use of linear instrumental variables methods in health services research and health economics: a cautionary note. Health Services Research 43(3): 1102-1120.

Wendland JR, Moya PR, Kruse MR, Ren-Patterson RF, Jensen CL, Timpano KR, Murphy DL. 2008. A novel, putative gain-of-function haplotype at SLC6A4 associates with obsessive-compulsive disorder. Human Molecular Genetics 17(5): 717-723.

Young SE, Smolen A, Corley RP, Krauter KS, DeFries JC, Crowley TJ et al. 2002. Dopamine transporter polymorphism associated with externalizing behavior problems in children. American Journal of Medical Genetics 114: 144-149.

Zhan L, Kerr JR, Lafuente MJ, Maclean A, Chibalina MV, Liu B, Burke B, Bevan S, Nasir J. 2010. Altered expression and coregulation of dopamine signalling genes in schizophrenia and bipolar disorder. Neuropathology and Applied Neurobiology, DOI: 10.1111/j.1365-2990.2010.01128.x. [Epub ahead of print]. 